\title{
Akut ve kronik bakteriyel prostatit olgularında tedavi yaklașımları
}

\author{
The treatment approaches in acute and chronic bacterial prostatitis cases
}

\author{
Sefa Resime
}

\section{öz}

Prostatit, ürologların günlük hasta pratiklerindeki en can sıkıcı problemlerden birisidir. Fizyopatolojisi tam olarak bilinmemektedir. Prostatit'lerin sınıflandırılmasında, Amerika Ulusal Sağlık Enstitüsü (NIH) konsensus panelinin 1999 yllındaki yeni klasifikasyonu kullanılmaktadır. Yirmi yaş üzeri erkeklerin; \%2-12'si hayatlarının belli bir döneminde prostatit semptomları yaşamakta ve bunların da yaklaşık olarak \%10'u, bakteriyel prostatit'tir (Akut veya kronik). Akut bakteriyel prostatit, ortaya çıkışı bakımından gürültülü bir tablo oluşturmaktadır. Akut bakteriyel prostatit; genel ürosepsis tablosu ile birlikte ciddi üriner enfeksiyon, irritatif ve obstrüktif işeme semptomları ile karakterizedir ve antimikrobiyal tedaviye hemen cevap vermektedir. Kronik bakteriyel prostatit (CBP) ise, tüm prostatit olgularının \%3-4'ünden sorumludur. 50 yaş altı hastalığı olarak bilinse de her yaş grubundan erkek etkilenebilmektedir. Kronik bakteriyel prostatit, genellikle hafif-orta pelvik semptomlar ve aralıklı akut üriner sistem enfeksiyonları ile ilişkilidir. Hastaların \%60-80'inde uzun süreli antimikrobiyal tedavi küratif olabilmektedir. İlk basamak tedavisi olarak, Florokinolon grubu ilaçlar verilmektedir. E. Koli ve Enterobacteriasea ailesinin diğer üyelerinin neden olduğu CBP'de bakteriyel eradikasyon, yaklaşı \%70'ler civarındadır. Optimal tedavi süresi olarak minimum 4 hafta tedavinin gerekliliği ileri sürülmektedir. Prostatit tablolarının birbirine dönüşme özelliği bulunmaktadır. Akut bakteriyel prostatit hastalarının \%10 kadarında kronik bakteriyel prostatit gelişebilmekte ve kronik bakteriyel prostatit hastalarının da yaklaşık \%10'u kronik pelvik ağrı sendromuna dönüşebilmektedir.

Anahtar Kelimeler: Bakteriyel prostatit, akut, kronik, tedavi

\section{Gíriș}

"Prostatit", ürologların günlük hasta pratiklerindeki en can sıkıcı problemlerden birisidir. Bunun nedenleri; prostatitin genel kabul gören bir tarifinin olmaması, tanı koyduru$\mathrm{cu}$ açık bir kriterinin bulunmaması ve bakteriyel prostatit'ler dışındakilerin tedavisinin tam olarak olmamasıdır.

Sütçü Imam Üniversitesi Tıp Fakültesi, Üroloji Anabilim Dalı, Androloji Bilim Dalı, Kahramanmaraş, Türkiye

Yazışma Adresi/ Correspondence:

Prof. Dr. Sefa Resim

KSU Tıp Fakültesi Dekanlığı, Üroloji Anabilim Dalı, 46050 Kahramanmaraş, Türkiye

Tel. $\quad+905056747952$

E-mail: sefaresim@gmail.com

Gelis/ Received: $\quad 02.07 .2019$

Kabul/ Accepted: 16.09 .2019

\section{ABSTRACT}

Prostatitis is one of the most annoying problems in urologists' daily patient practices. Its physiopathology is not fully known. The new classification of the American National Institute of Health (NIH) consensus panel in 1999 is used for the classification of prostatitis. Men over the age of $20 ; 2-12 \%$ of them experience prostatitis symptoms in a certain period of their lives, and about $10 \%$ of them are bacterial prostatitis (acute or chronic). Acute bacterial prostatitis creates a noisy picture in terms of its occurrence. Acute bacterial prostatitis; It is characterized by severe urinary infection, irritative and obstructive voiding symptoms together with the general urosepsis table and responds immediately to antimicrobial therapy. Chronic bacterial prostatitis (CBP) is responsible for $3-4 \%$ of all prostatitis cases. Although it is known as a disease under 50 , men can be affected from any age group. Chronic bacterial prostatitis is often associated with mild to moderate pelvic symptoms and intermittent acute urinary tract infections. Longterm antimicrobial therapy can be curative in $60-80 \%$ of patients. As first-line therapy, fluoroquinolone drugs are given. Bacterial eradication in CBP caused by E. Koli and other members of the Enterobacteriasea family is about $70 \%$. It is suggested that a minimum of 4 weeks of treatment is required as an optimal treatment period. Prostatitis tables have the ability to transform into each other. About $10 \%$ of patients with acute bacterial prostatitis can develop chronic bacterial prostatitis, and about $10 \%$ of patients with chronic bacterial prostatitis can turn into chronic pelvic pain syndrome

Keywords: Bacterial prostatitis, acute, chronic, treatment
Ayrıca, fizyopatolojisi de tam olarak hala bilinmemektedir. [1] Gerçek bakteriyel prostatitler hariç, 1906 yılında Young ve ark. tarafından bildirilenlerin dışında prostatit hakkında çok az bilgiye sahibiz. ${ }^{[2]}$ Prostatit'ler ile ilgili yapılan çalışmaların hiç birisinde hastaların çalışmaya dahil edilme kriterleri aynı değildir. Sadece birkaç yazar prostatiti tarif ettiğinden dolayı, bir çalışmadaki bulguları diğer çalışmaların bulguları ile karşılaşıırma yapılamamaktadır. Bu oldukça kötümser görünüşe rağmen, Young ve ark.'nın geliştirdikleri temel prensipleri günümüzde hala kullanmaktayı.

\section{TARIHÇE}

M. Ö. 350 yılında, Herophylus'un prostatı bir organ olarak tarif etmesinden sonra ${ }^{[3]}, 1800$ yılında ilk defa Belfield adlı araştırmacı, prostatiti ayrı bir hastalık grubu olarak 
tanımlamıştır. ${ }^{[4]} 1815$ yılında Legneau, prostat bezi iltihabının inflamatuvar bir süreç olduğunu, 1838'de de Verdes, prostatitin patolojisini açıklamıştır. 1906 yılında, Young ve ark., modern anlamda prostatit hastalığının kliniğini (patolojisini, mikroskobik değerlendirmesini) ortaya koymuşlardır. ${ }^{[2]}$ Hitchens ve Brown ise, 1913'de prostatitin bakteriyel ve sitolojik değerlendirmesini yapmıştır. ${ }^{[4]} 20$. yüzyıla kadar prostat iltihabının tedavisinde ilk seçilecek prostatik masaj iken, 1930'larda prostatitin klinik semptomları standardize edilerek tedaviye sulfanamidler eklenmiştir. 1950-60'larda ise, prostat masajı ile prostat akıntısının önemi ortaya konulmuştur (expressed prostatic secretion=EPS) ${ }^{[4]}$ Prostatit üzerine yapılan modern klinik araştırmalar ise, Stamey ve ark. ları ile başlamıştır ve onların geliştirdikleri prensipleri bugün hala kullanmaktayız. Prostatit'lerin ilk sınıflandırılması 1968 yılında Meares ve Stamey tarafindan yapılmış ${ }^{[5]}$ ve 10 yıl sonra, Drach ve Stamey tarafından revize edilmiştir. ${ }^{[6]}$ Her iki durumda da klasifikasyon, prostat sıvı kültürlerinden elde edilen bulgular ve semptomlara dayandırılmıştır. Meares adlı araştırmaC1, erkeklerde enfeksiyonların uretraya, prostata veya mesaneye lokalizasyonunu saptamaya yarayan segmente edilmiş kültür tekniklerini geliştirmiştir. ${ }^{[7]} \mathrm{Bu}$ sınıflamaya göre;

Kategori I: Akut bakteriyel prostatit,

Kategori II: Kronik bakteriyel prostatit,

Kategori III: Kronik prostatit/kronik pelvik ağrı sendromu (CP/CPPS),

Kategori IV: Asemptomatik inflamatuvar prostatit.

NIH 1999 sınıflamasında kategori I ve II tanımı, akut ve kronik bakteriyel prostatit için kullanılmıştır. Prostatitin nonbakteriyel bir versiyonu olan kategori III (gösterilebilir bir bakteriyel enfeksiyonun yokluğunda alt üriner sistem semptomları (LUTS) ve genitoüriner ağrı ile karakterizedir), IIIA (inflamatuvar) veya IIIB (non-inflamatuvar-önceki tanımlamada prostatodini olarak isimlendirilen) olmak üzere ikiye ayrılmıştır. IIIA ve IIIB arasındaki farkta, eksprese edilen prostat sekresyonlarında, post-prostatik masaj idrarında veya semen örneklerinde lökositlerin varlığı veya yokluğu temel alınmaktadır. Tip IIIA; semende, prostat masajı sonrası alınan idrar örneğinde veya eksprese edilen prostatik sekresyondaki (EPS) beyaz kan hücrelerinin (lökosit) varlı$\breve{g}$ i ile karakterizedir. Tip IIIB kategorisine giren hastalar ise, semen, VB3 veya EPS örneklerinde inflamasyon bulgusu olmaksızın pelvik ağrıya sahiptir. Son olarak, kategori IV'te, Asemptomatik inflamatuvar prostatit (Histolojik prostatit) olarak sendrom tanımına ilave edilmiştir.

Prostatik inflamasyon bulgusu gösteren asemptomatik hastaların olduğu oldukça yaygın bir durumu ifade eden kategori III-kronik prostatit/kronik pelvik ağrı sendro$\mathrm{mu}$ (CP/CPPS), semptomatik prostatit subtiplerinin en sık formunu oluşturmaktadır (prostatit tanılarının \%9095'ini oluşturmaktadır. ${ }^{[7]}$ Yeni sınıflandırmada, kronik prostatit'de ağrı temel belirti olarak kabul edilmiş ve kr. prostatit'li hastaları diğer genitoüriner yakınması olanlardan ayırt etmedeki en uygun kriter olduğu belirtilmiştir. ${ }^{[5]}$

\section{EPIDEMIYOLOJI}

20 yaş üzeri erkeklerin; \%2-12'si hayatlarının belli bir döneminde prostatit semptomlarına sahip olmakta ve bunların da yaklaşık olarak \%10'u bakteriyel prostatit'tir (Akut veya kronik). ${ }^{[8-12]}$ Yapılan bir çalışmada, Kanada'lı erkeklerin yaklaşı olarak \%9'unun prostat semptomları ile tecrübelendiği, \%6'sında bu semptomların bir sıkıntıya yol açtığı ve 1/3'ünde de bir yıllık takiplerin sonucunda semptomların remisyona uğradığı saptanmıştır. ${ }^{[11,13]}$ Başka bir çalışmada ise, klinik olarak anlamlı prostatit semptomları olan erkeklerin oranının, üroloji polikliniklerine başvuran erkekler arasında $\% 3$ olduğu bildirilmiştir. ${ }^{[14]}$ Prostatit hastalarının \%10'undan daha azı akut veya kronik bakteriyel prostatit'den 1 stırap çekmektedir. Prostatit olgularının yaklaşık olarak \%90-95'ini oluşturan CP/CPPS, erkeklerin \%10-14'ünü etkilemektedir. 50 yaş altı erkeklerdeki en sık ürolojik bozukluk, kategori IIIa ve IIIb'dir. ${ }^{[10-12]}$

\section{FIZYOPATOLOJi}

Prostatik inflamasyonun, prostatın büyümesini, BPH semptomlarının progresyonunu ve de prostatiti etkileyen önemli bir faktör olduğu düşünülmektedir. Kronik inflamasyon/nöroinflamasyon; kuşattığı nöral dokuları moleküler, yapısal ve fonksiyonel düzeylerde etkileyen immun sistemin doğal, düzensiz akut faz yanıtının bir sonucudur. Klinik gözlemler, $\mathrm{BPH}$ ve CP/CPPS ile kronik inflamasyonun korele olduğunu ileri sürmektedir.

Bakteri; assandan uretra, prostatik kanalların içerisine idrarın reflüsü, hematojen yolla veya prostata giren biyopsi iğnesi aracılı̆̆ıyla bakterinin doğrudan inokülasyonu arac1lığıyla prostatı enfekte edebilmektedir. Akut ve kronik bakteriyel prostatitte baskın patojenler Enterobacteriaceae olmasına rağmen, Enterococcỉlerin de gittikçe artan rolü bildirilmektedir. Bu patojenlerin pek çok suşu biyofilm formu oluşturma yeteneği ve "multi-drug direnci" göstermektedir. Cinsel yolla geçen enfeksiyon (STI) ajanları, özellikle Klamidya trakhomatis ve Mikoplazma genitalium, kronik bakteriyel prostatitin etken patojeni olarak yine akla getirilmelidir. Bu nedenle, STI ajanları hem hastada hem de cinsel eşinde moleküler metodlar ile araştırılmalıdır.

Prostatit'e yol açtı̆̆g ileri sürülen mekanizmaların bazıları şunlardır; ejakülatuvar ve prostatik kanallar içerisine 
enfekte idrarın reflüsü, eksternal uretral mea'dan assandan uretral bir enfeksiyon, rektumdan doğrudan veya lenfatik yolla yayılım, hematojen yolla yayılan enfeksiyon.

\section{Risk Faktörleri ${ }^{[13]}$}

- $\mathrm{BPH}^{*}$,

- Prostatın manipülasyonu*,

- Sistoskopi,

- Transuretral cerrahi,

- Uretral kateterizasyon,

- TRUSG-prostat biyopsisi,

- STI öyküsü*,

- Fimozis,

*Enfeksiyon için yüksek risk

\section{Akut Bakteriyel Prostatit (NIH kategori-I)}

Akut bakteriyel prostatit (ABP) ile ilgili büyük seriler bulunmamaktadır. Ortaya çıkışı bakımından gürültülü bir tablo oluşturmaktadır. Akut başlangıç göstermektedir. Akut bakteriyel prostatit; genel ürosepsis ile birlikte ciddi üriner enfeksiyon, irritatif ve obstrüktif işeme semptomlar1 ile karakterizedir. Antimikrobiyal tedaviye hemen cevap vermektedir. Geçen zaman içerisinde sınıflandırılması herhangi bir modifikasyona uğramamıştır. Tanı, klinik semptomların varlığına ve idrarda bir patojenin izolasyonuna dayanmaktadır. Yeterli antibiyotik tedavisi vasıtasıla olguların çoğunda semptomların komplet remisyonu nedeniyle bu hastalığa gösterilen ilgi genellikle çok azdır (çalışma yapma anlamında).

ABP ile ilgili yayınlanmış büyük seriler olmadığ patolojinin klinik özellikleri tam olarak tanımlanamamaktadır. ABP'li hasta profilini tarif etmek amacıyla farklı iki alt grubu olduğu ileri sürülmektedir ${ }^{[14]}$ :

1. Manipülasyona sekonder Akut Prostatit (MABP-\%10),

2. Spontan olarak oluşan Akut Prostatit (SABP_\%90)

Manipülasyona sekonder akut prostatit (MABP-\%10): ABP'nin başlamasından önceki 30 gün içerisinde alt üriner sistemin manipülasyonuna uğrayan hastalar bu gruba gitmektedir (prostat biyopsisi, ürodinami testi, uretral yolla bir kateterin yerleştirilmesi gibi). Bu gruptaki hastalar genellikle daha yaşlı ve daha büyük bir prostat volümüne sahiptir. Prostat absesi gelişim riski daha yüksek ve etken mikroorganizma, genellikle E. koli dışındaki ajanlardır. İyatrojenik olduğundan, miks tipte enfeksiyon oranı ve Pseudomonas spp.'nin oranı anlamlı olarak daha yüksektir.

Spontan olarak oluşan Akut Prostatit (SABP-\%90): ABP oluşuma yol açan bir nedenin saptanamadığı hasta grubunu oluşturmaktadır. Klasik ABP özelliklerine en uygun olan gruptur. Bu gruptaki hastalar genelde genç yetişkinlerdir. Bilinmeyen etiyoloji ile önceden de benzer atakların olduğu öyküde belirtilebilmektedir.

Akut bakteriyel prostatit semptomları: Genel ürosepsis ile birlikte ciddi üriner enfeksiyon, irritatif ve obstrüktif işeme semptomları ile karakterizedir;

Sistemik: Halsizlik, Ateş, Üşüme-titreme ve Terleme

Lokal: Dizüri, Frequency, Urgency, Şiddetli perineal ağrı vb.

En ciddi komplikasyonu, bakteriyemi ve ürosepsis'tir (daima potansiyel bir risktir). ${ }^{[11,13,15]}$

Fizik Bakı: Abdomen, eksternal genitaller, perine ve prostat irdelenmelidir (4:C).

İnceleme sırasında fazla basınç uygulanması, tabloyu ağırlaştırabilir, bu açıdan dikkatli olunmalıdır. Parmakla rektal muayene esnasında; prostatın duyarlı olduğu kolayca fark edilmektedir. Prostatta 1sı artışı, ödem, hassasiyet ve abse saptanabilir. Prostat masajı önerilmemektedir (bakteriyemi riskinden dolayı kontrendikedir).

İdrar analizi ve kültürü: Zorunludur (2:A). Pyüri ve nitrit testi (+)'liği gözlenmektedir. Nitrit ve lökosit için idrar dipstick testleri; \%95 pozitif prediktif değere, \%70 negatif bir prediktif değere sahiptir.

Serum: Kan kültürü ve tam kan sayımı yararlıdır $($ Lökositoz +).

PSA ölçümü, önerilmemektedir (3:C). ABP nedeniyle yükselmiş PSA genellikle kafa karışıklığına yol açmaktadır. PSA düzeyi, tedavi sonrası 1. ayda hastaların \%50 sinde normal değerlere gerilemektedir. PSA düzeyinin tam olarak oturması için 3 aya kadar beklenmelidir. PSA ölçümü, tanı ve tedavinin etkinliği noktasında kesin bir bilgi vermemektedir. ${ }^{[16-18]}$

\section{ETKEN}

En yaygın nedeni, GIS kaynaklı enterik bakterilerden Enterobacteriacea ailesidir (E. coli, \%50-80 olguda etken mikroorganizmadır). Diğer Enterobacteriacea patojenleri (K. pneumoniae, P. mirabilis): \%10-30; Enterococcus faecalis: \%5-10; Nonfermentatif gram-negative basiller (P. aeruginosa): $<\% 5$. Ejakulat analizi ve prostat biyopsisinin yeri bulunmamaktadır. ${ }^{[17-19]}$ (Nonfermentatif: su içeren ortamlardan köken alan, minimal üreme koşullarında üreyebilen ve virulans yönünden çeşitlilik gösteren bir organizma grubu). 
Görüntüleme: Tercihe bağlıdır (2:A), Başlangıçta yeri yoktur (3:B). ${ }^{[20]}$

TRUSG veya BT: başlangıç tedavisine dirençli olgularda prostat absesini dışlamak için endikedir.

Mesane USG: ciddi obstrüktif semptomları veya üriner retansiyon şüphesi olanlarda endikedir.

Multiparametrik MRI: Akut prostatit'te T2W1'de düşük sinyal yoğunluğu ve kısıtlı difüzyon özelliği ön plandadır, ancak prostat kanseri ile örtüşen "enhancement" paternleri de görülebilmektedir. Prostat absesi dışında, ayırıcı tanıda klinik bulgular dikkate alınmalıdır.

Pozitron Emisyon Tomografisi (PET): Kategori I prostatitin rezolüsyonunun değerlendirilmesi mümkün olabilmektedir.

Tedavi: ABP tedavi edilirken şu faktörler mutlaka göz önünde bulundurulmalıdır; potansiyel ürosepsis, antimikrobiyal ajanın seçimi, hastaneye yatırılma için risk faktörlerinin olup olmaması, üriner retansiyon gelişimi (\%10). ${ }^{[21]}$

\section{ABP'te hastaneye yatırma kriterleri (3:B):}

1. Sistemik hastalık veya ürosepsis bulgularının olması; yüksek ateş (hiperpreksi), taşikardi, takipne, hipotansiyon vb.,

2. Ciddi işeme disfonksiyonu veya üriner retansiyon,

3. Ayaktan tedavinin yetersiz olmasi,

4. Oral ilaç alımının tolere edilememesi; Uzamış kusma, ciddi dehidratasyon

5. Yüksek riskli hastalar: DM, immunosupresif hasta, yaşlı veya prostat abseli hastalar

6. İlaca direnç için risk faktörlerinin olması: son zamanlarda florokinolon kullanımı, yakın zamanda transuretral manipülasyon (sonda takılması, TUR-ED, TUR-P gibi) ve transrektal prostatik manipülasyon (prostat biyopsisi).

Antimikrobiyal ilaçların kullanımı (2:A): Antimikrobiyal tedavinin başarısı; ilacın prostat dokusu ve sekresyonlarında yüksek konsantrasyonlarda açığa çıkması gibi farmakokinetik karakteristiğine ve Antibakteriyel aktivitesine bağlıdır. Kültür sonuçları çıkana kadar ampirik tedaviler uygulanmalıdır; florokinolon grubu bir ilaç, bir beta-laktamaz inhibitörlü geniş spektrumlu bir penisilin, 3. kuşak sefalosporin gibi. Bu üç grup ilaç, bir aminoglikozid ile kombine edilebilir. Ciddi bir şekilde hasta olanların başlangıç tedavisinde; ürosepsis bulguları normalleşene ve ateşsiz bir döneme kadar antibiyotikler, yüksek dozlarda intravenöz yolla verilmelidir. Bu öneri, komplike olmuş
UTI'ler ve ürosepsisin tedavisinde temeldir. Ciddi hastal1ğ veya kusması olmayan hastalar, oral bir florokinolon ile tedavi edilebilir.

Antimikrobiyal tedavinin seçimi ve süresi, tecrübe ve uzman görüşlerine dayanmaktadır ve birçok kontrolsüz klinik çalışma ile de desteklenmektedir.

\section{Florokinolon'lar}

Avantajları; Oral biyoyararlanımı iyidir. Oral ve IV formları mevcut, prostata iyi penetre olmaktadır. Çoğu bakteriyel patojene ve birçok atipik patojene karşı etkindir ve organizmanın biyofilm oluşturmasına karşı etkili olabilmektedir.

Dezavantajları; Diğer ilaçlarla olan potansiyel etkileşimi, çeşitli bilinen toksisitesinin olması ve rölatif olarak pahalı olmasidır.

48-72 saat sonra; enfeksiyon parametrelerinin normale dönmesi, semptomların hafiflemesi, kliniğinin düzelmesiyle beraber, kültür sonucuna uygun oral bir antibiyotikle tedaviye 2-4 hafta devam edilebilir. Kür oranı, yaklaşık \%80'dir.

Trimetoprim-sulfametoksazol (TMP/SMX), en sık patojen olan E. coli ( >\%10-20) direncinin olduğu bölgelerde ilk basamak tedavisi olarak önerilmemektedir. ${ }^{[22,23]}$

\section{DIĞER TEDAVI YÖNTEMLERi}

35 yaş altındaki hastalarda, tedaviye tetrasiklin de eklenmelidir.

Nonsteroidal anti-inflamatuvar ajanlar: Ateşi de kapsayan semptomları azaltmak amacıyla verilebilmektedir.

Alfa-blokerler: Orta-ciddi obstrüktif semptomları olanlarda üriner retansiyon riskini azaltmak amaciyla kullanılabilmektedir. Antibiyotik ile beraber, alfa bloker kullanımı, semptomlarda gerileme ve nüks sıklığında azalma sağlayabilmektedir. Enfeksiyonun olası hematojen kaynağını bulmak (örn., S. aureus endokarditi), komplike enfeksiyon (sepsis) veya immun supresif hastalarda ve vücut sıcaklığı $>38,4^{\circ} \mathrm{C}\left(101,1^{\circ} \mathrm{F}\right)$ ise kan kültürleri alınmalıdır.

\section{Drenaj}

Üriner drenaj (3:B): Ciddi obstruktif işeme semptomları veya üriner retansiyonu olan hastalar da, kısa süreli küçük çaplı bir uretral kateterizasyon önerilmektedir. Suprapubik kateter yerleştirilmesi, uretral kateteri tolere edemeyen hastalar için bir seçenektir (uretral kateter, kronik prostatit riskini artırabilmektedir). 
Prostat abse drenaj1 (4:A): Ateş >36 saatten uzun sürüyorsa, prostat absesini dışlamak için görüntüleme yöntemleri kullanılmalıdır. Prostat absesinde drenaj veya konservatif tedavi yaklaşımları uygulanabilmektedir. Abse boyutu $<1$ $\mathrm{cm}$ ise, konservatif tedavi; $\geq 1 \mathrm{~cm}$ ise, tek bir aspirasyon ile veya devamlı drenaj ile tedavi seçilebilir. Drenaj için genellikle, transuretral yol seçilmektedir (perineal ve rektal yolla da abse drenajı yapilabilmekte).

TRUSG-prostat biyopsisi sonrası ABP: Etken, E. coli ise yüksek oranlarda antimikrobiyal ajana direnç vardır. Florokinolon'a dirençli bakteriyi ve beta-laktamaz üreten E. coli yi de kapsayacak geniş spektrumlu bir antibiyotik başlanmalıdır. 3. kuşak sefalosporin ve imipenem bile bazen etkin bir tedavi sağlayamayabilmektedir. ${ }^{[2]}$

\section{Kronik Bakteriyel Prostatit (CBP) (NIH kategori-II)}

Tüm prostatit vakalarının \%3-4'ünden sorumludur. "Semptomların en az üç aydır sürmesi" olarak tanımlanmaktadır. 50 yaş altı hastalığı olarak bilinse de her yaş grubundan erkek etkilenebilmektedir. Kronik bakteriyel prostatit'li erkeklerin çoğu, pelvik ağrı ile karakterize olan (perineal, suprapubik, testiküler, penil) değişik üriner sistem semptomları ve cinsel disfonksiyon bulguları (primer olarak ağr ejakülasyon ile ilişkilidir) ile kendini gösteren CP/CPPS'ye sahiptir. ${ }^{[11,13]}$ Kronik bakteriyel prostatit, genellikle hafif-orta pelvik semptomlar ve aralıklı akut üriner sistem enfeksiyonları ile ilişkilidir. Hastaların \%60-80'inde uzun süreli antimikrobiyal tedavi küratif olabilmektedir. ${ }^{[25]}$ CBP'li hastaların yaşam kalitelerinin; Crohn hastalı̆ı̆ Angina pektoris, ve DM'li hastalarla benzer olduğu bildirilmiştir. Etiyolojisinde, idrar yolu enfeksiyonlarına neden olan mikroorganizmalar bulunmaktadır. Tekrarlayan idrar yolu enfeksiyonları ve prostatik sıvıda aynı bakterinin gösterilmesiyle tanı konulmaktadır (özellikle aynı etkene bağlı yineleyen üriner enfeksiyonlar, kronik bakteriyel prostatiti akla getirmelidir).

Prevalansı: Tüm yaş gruplarında \%8-14; 50 yaş altı erkeklerde $\% 11,5 ; 50$ yaşından büyük erkeklerde ise $\% 8,5$ tir. Ürolojik muayenelerin \%8'inin bu hastalık nedeniyle yapıldığı ve bu oranın gittikçe arttığı bildirilmektedir. $[11,13,26-29]$

Semptomları: Genito-üriner ağrı (perineal, suprapubik, testiküler, penil ağrı), dizüri, şeffaf akıntı ve alt üriner sistem semtomları. Cinsel disfonksiyon bulguları olabilmesine karşın (primer olarak ağrılı ejakülasyon) sistemik enfeksiyon bulguları yoktur. Tanıdaki en önemli kriter, \%25-43 oranında tekrarlayan üriner sistem enfeksiyonu anamnezinin olmasıdır.
Fizik Bakı: Zorunludur (4:C). Abdomeni, eksternal genitalleri, perineyi, prostatı ve pelvik tabanı içermelidir. Fizik muayenede, prostat, normal boyut ve kıvamdadır.

Laboratuvar Analizleri: Zorunludur (2:A). Alt üriner sistemin mikrobiyolojik olarak lokalizasyonunu sağlamaya yönelik olmalıdır. 4 kap testi veya 2 kap testi (pre-ve post-prostatik masaj testi [PPMT]).

Önerilen test (3:A), Meares ve Stamey tarafindan tanımlanan 4 kap testi'dir ve CBP'in tanısı için standart ölçüdür. 4 kap testinde, mesane, prostat veya uretraya bakterinin lokalizasyonunu veya inflamasyonunu saptama amaçlanmaktadır. ${ }^{[5,30]}$

4 kap testinin yapılışı: Dört adet steril idrar kabı örneği alınır ve 1'den 4'e kadar sırayla numaralandırılır. İlk önce, uretra örneğini yansıtması açısından 1 no'lu idrar kabına 10 cc kadar idrar yapılır ve ağzı kapatılır (Voided Bladder 1) (VB1). Sonra, orta akım idrar örneği 2 no'lu kaba yapılır ve mesane örneğini yansıtır (VB2). Daha sonra, 3 no'lu idrar kabına prostat masajı ile elde edilen sekret alınır (expressed prostatic secretions-EPS). Son olarak 4 no'lu kaba prostat masajı sonrası 10 cc kadar idrar yapılır (VB3) ve hepsi mikroskopik değerlendirmeye tabi tutularak kültüre yollanır.

VB1'deki bakteri varlı̆̆ı veya lökosit, uretriti; VB2'deki bakteri varlığı veya lökosit mesane enfeksiyonunu (primer veya eşlik eden) işaret etmektedir. Prostat sekretinde ve VB3 örneğinde; inflamatuvar hücre varlığının ve bakteri koloni sayısında idrar 2 örneğine (VB2) kıyasla daha fazla bakteri bulunması, kronik bakteriyel prostatit için tanı koydurucudur.

Ayrıca, prostat sekretinde büyük büyütmede $>10$ lökosit saptanması da tanıyı desteklemek açısından önemlidir. Bununla birlikte, olguların ancak \%5 ila10'unda, etken mikroorganizma izole edilebilmektedir. Bu yüzden, çoğu hastaya ampirik tedaviler uygulanmaktadır.

2 kap testi: Dört kap testi, genellikle rutin olarak yapılmadığından dolayı, 1985 yılında ilk defa Weidner ve Ebner, yapılması daha pratik olan iki kap testini önermişlerdir. Bu test, 1997 yılında Nickel tarafından popülarize edilmiştir. Avantajları; basit ve uygulaması kolay, \%91 özgüllük ve duyarlıllğa sahiptir.

Yapılışı; birinci tüpe, prostat masaj öncesi orta akım idrarı, ikinci tüpe ise, prostat masajı sonrası ilk 10 cc'lik idrar konulmakta ve incelenmektedir. NIH kronik prostatit kohort çalışma grubu, \%96'dan daha fazla oranda dört kap testi ile aynı tanının konulduğunu göstermiştir. ${ }^{[16]}$

Semen kültürleri: kanıt düzeyi sınırlı olduğundan dolayı, önerilmemektedir (3:D). CBP'li erkeklerin saptanmasında 
anlamlı olarak yardımcı olduğu gösterilememiştir. Semen kültürlerinde birden fazla mikroorganizma üreyebilmektedir. Aksesuar glandlardan, ya da kontaminasyonla gelen mikroorganizmalar nedeniyle bu örnekler, tekrarlayan UTI'lere neden olan aynı organizma kültürde üremediği müddetçe CBP tanısında semen kültürleri pek değerli değildir,

TRUSG: Önerilmemektedir (3:B). Prostatit'ler arasındaki ayırımı güvenilir bir şekilde yapabilme yeteneğinde değildir. Spesifik bir endikasyon olduğunda opsiyonel olarak düşünülmelidir (4:D).

Ürodinami: Opsiyonel'dir (4:D). Üroflov, obstrüksiyonu konfirme etmede yardımcı olabilmektedir. Prostatitin kategorilerine göre ayırıcı tanılarını güvenilir bir şekilde yapabilme yeteneğinde değildir. Sadece mesane problemleri ve/veya obstrüksiyonu dökümante etmeye yardımcı olabilmektedir.

\section{PSA Ölçümü}

ABP ve CBP'li erkeklerde sirasılla \%60 ve \%20'sinde PSA artmaktadır. PSA düzeyleri, hastaların $\% 40$ 'ında antibiyotik tedavisinden sonra azalmaktadır (klinik ve mikrobiyolojik düzelme ile koreledir). Prostatitte serbest veya total PSA ölçümünün pratik tanısal değeri bulunmamaktadır.

\section{TEDAVi}

İlk basamak tedavisi, florokinolon grubu ilaçlardır. E. coli ve Enterobacteriasea ailesinin diğer üyelerinin neden olduğu CBP'de bakteriyel eradikasyon, yaklaşık \%70'ler civarındadır. Pseudomonas aeruginosa ve enterokokların neden olduğu CBP'ler, antimikrobiyal tedaviye daha kötü yanıt vermektedir. Optimal tedavi süresi, kontrollü çalışmalarda tarif edilmemesine rağmen, minimum 4 hafta tedavi yapılması gerektiği ileri sürülmektedir.

Florokinolonlara karşı direnç, 2000 yılından beri gittikçe artmaktadır. Florokinolon direncindeki progresif artışın nedenleri şunlardır; karbapenemler dışındaki diğer çoğu beta-laktam antibiyotiklere direnç sağlayan enzimler olan genişletilmiş $\beta$-laktamaz'ların (ESBL: extended spectrum betalactamases) yayılması (bu enzimler, florokinolonlar ve aminoglikozitler gibi diğer antimikrobiyal sınıflara direnç barındıran genlerin ekspresyonu ile de sıkça ilişkilidir (Multidrug rezistans-MDR. MDR, antimikrobiyallerin en az üç farklı sınıfına direnç gösteren), bakteriyel direncin hızla artması ve yeni geliştirilen antibiyotiklerin sayısında azalma. Tüm bu faktörler, CBP'nin tedavisi için eldeki seçenekleri sınırlamaktadır. ${ }^{[31-33]}$

Hangi antibiyotiği kullanmalı? CBP tedavisinde antibiyotiklerin prostat dokusuna geçişi önemlidir. Çoğu antibiyotik, prostat epiteline geçmelerini inhibe eden biyolojik sıvılardaki iyonizasyonları sonucunda ya zayıf asidlerdir ya da zayıf bazlardır. Normal insan prostat sıvısının pH'ı, - 7,3'tür. CBP'li kişilerde ise prostat sıvısı belirgin derecede alkali olmaktadır (ort. pH: 8,34). Bu nedenle, sadece birkaç antibiyotik prostatta terapötik konsantrasyonları oluşturabilmektedir. Kinolonlar, sulfonamidler, makrolidler ve tetrasiklinler, prostat dokusuna daha yüksek oranda nüfuz edebilmektedir. Prostatın içine moleküler penetrasyonu arttıran özellikler; yüksek lipid çözünürlüğü, iyonizasyonu düşük dereceli, yüksek bir çözünme katsayısı (pKa, prostatın içine iyonize olmayan bileşiğin difüzyonuna izin verir), proteine bağlanmada düşüklük ve küçük moleküler boyut'tur $(\mathrm{MA}<1000) .{ }^{[29,32]}$

\section{Prostatik Sekresyonda/Dokuda Antibiyotiklerin Difüzyonu}

Beta-laktam ilaçların, yağda çözünürlükleri düşüktür ve düşük bir pKàya sahip olduklarından, prostatik sıvı içerisine kötü bir şekilde penetre olmaktadır. Florokinolonlar, amfoteriktir ve medyuma bağlı olarak ya nötral moleküller ya da zwitterion (hem pozitif hem de negatif yük taşıyan bir molekül) olarak daha kompleks bir davranış sergilemektedir.

Köpeklerde yapılan deneysel çalışmalar bu durumu konfirme etmesine rağmen, deneysel hayvan çalışmaları insan kliniğine kolaylıkla transfer edilememektedir. Çünkü, insanlarda prostat sekresyonunun $\mathrm{pH}^{\prime} 1$ daha az asidiktir ve kronik prostatitte artmaktadır.

Antibiyotik uygulanmasından sonra endoskopik yolla prostat rezeksiyonları yapılan hastalardan elde edilen doku örneklerinde ölçülen antimikrobiyallerin doku konsantrasyonlarının değerlendirilmesi sonucunda, prostatik dokularda florokinolonların iyi penetre olduğu gösterilmiştir. ${ }^{[34]}$

Tedaviye dirençli CBP (NIH kategori II): Florokinolon tedavisine dirençli CBP'lerde; prostata lokalize olan üropatojen konfirme edilmelidir. Böyle durumlarda sorunu gidermek için eldeki olası seçenekler şunlardır;

a. Hali hazırda kullanılmakta olan antibiyotiklerin dozajının arttırılması,

b. Antibiyotiklerin kombinasyonu,

c. Daha önce kullanılmamış olan antibiyotiklerin kullanilması, ve

d. Daha önce kullanılmış olan "eski" antibiyotiklerin yeniden verilmesidir.

Tedaviye dirençli CBP olgularında tedavi süresi 8-12 hafta olmalıdır. 


\section{Antibiyotiklerin Kombinasyonu}

Antibiyotik tedavisinin başarı oranlarını iyileştirecek bir diğer seçenek, iki antibiyotiğin birlikte verilmesidir. Tetrasiklin (özellikle doksisiklin ve minosiklin) ve makrolid grubu antibiyotikler, CBP'nin kombine tedavisinde yoğun bir şekilde kullanılmaktadır. İntrasellüler patojenlerin oluşturduğu enfeksiyonların tedavisinde klinik ve mikrobiyolojik etkinlik açısından iki grup arasında fark saptanmamaktadır. Klamidyal prostatitin tedavisinde, makrolid'lerin florokinolonlardan daha etkili olduğu gözlenmektedir. Özellikle makrolidler, biyofilm büyümesini azaltma yeteneklerinden yararlanmak için kinolonlarla birlikte verilebilmektedir.

Örneğin, Siprofloksasin (750 mg/gün) + Azitromisin (500 mg, üç defa/hafta, altı hafta) ile kombine bir tedavide mikrobiyolojik eradikasyon oranı \%64,2'dir. İlk tedavi siklusu sonunda reenfeksiyon veya enfeksiyonun sürdügü hastalarda, ikinci bir 6 haftalık tedavi siklusu sonrasında ise mikrobiyolojik eradikasyon oranı \%83,9'dur. Kombinasyon tedavisi, hem geleneksel üropatojenler hem de nadir patojenler ile oluşan enfeksiyonların yüksek eradikasyon oranlarını sağlamaktadır.

\section{Tetrasiklinler}

Avantajları; oral olarak kullanılabilirliği, oral ve intravenöz formüllerinin olması, pahalı olmaması, birçok atipik patojene ve metisiline dirençli stafilokok aureus suşlarına (MRSA) karşı etkin olması.

Dezavantajları; Pseudomonas'a karşı etkili değil, birçok Enterobacteriaceae'a karşı etkinliği sınırlıdır, enterokoklar için uygun değil, böbrek veya karaciğer hastalığında kullanırken dikkatli olunmalı ve fotosensitiviteye neden olabilmekte.

\section{Makrolidler:}

Avantajları; uygun oral kullanımına sahip olması, gram pozitif bakterilere karşı etkili fakat çoğu MRSA suşlarına karşı etkin değil, prostate iyi penetre olması, atipik patojenlere karşı biraz etkili, rölatif olarak pahalı olmaması, rölatif olarak emniyetli olması ve biyofilm oluşturan organizmalara karşı aktif olabilmesi.

Dezavantajları; sadece Azitromisin'in intravenöz olarak kullanılabilmesi, gram negatif bakterilere karşı etkili olmaması ve gastrointestinal bozukluklara rölatif olarak sıkça yol açması.

Piperasilin-tazobaktam, Seftolozan-tazobaktam, Seftazidim-baktam, Meropenem: Spesifik farmakokinetikleri ve farmakodinamikleri ile ilgili olarak yapılan çalışmalar, duyarlı gram negatif prostatitte kullanılabileceğini göstermesine rağmen, prostat dokusuna penetrasyonları ve prostatit'te kullanımları hakkında veriler açık değildir. $\mathrm{Bu}$ nedenle, prostat enfeksiyonlarının tedavisinde ilk basamak ajanlar olarak düşünülmemelidir. ${ }^{[34,35]}$

\section{DAHA ÖNCE KULLANILMAMIȘ OLAN ANTIBIYYTIKLERIN KULLANILMASI}

\section{Fosfomisin}

Duyarlı profilinin olması, prostata iyi penetrasyonu ve oral olarak verilebilme (3 gram, her 48 veya 72 saatte, 2-6 hafta) gibi avantajları bulunmaktadır. Antimikrobiyallara dirençli E. koli tarafından oluşturulan bakteriyel prostatitli hastalarda; klinik kür oranları \%50-77 ve mikrobiyolojik eradikasyon oranları $>\% 50$ 'dir (33). Normal prostat dokusunda yeterli konsantrasyonlara eriştiğinden dolayı, dirençli kronik bakteriyel prostatitlerde alternatif bir tedavi seçeneğidir. ${ }^{[36]}$

\section{DAHA ÖNCE KULLANILMIS OLAN "ESKI" ANTIBIYYOTIKLERIN YENIDEN VERILMESI}

\section{Aminoglikozidler}

Diğer antibiyotiklere göre prostatik dokuda ve sıvılarda daha az diffüze olmasına rağmen, Kanamisin ve streptomisin gibi bazı aminoglikozidler, CBP'li hasta serilerinde başarılı bir şekilde kullanılmaktadır. Aminoglikozidlerin tek başına veya bir beta-laktam antibiyotik ile kombine olarak verilmesinin, CBP'li hastaların \%79'unda klinik remisyon ve mikrobiyolojik eradikasyon sağladığı gözlenmiştir. Sensori-nöral sağırlığa predispoze mutasyonlar için hastaların genetik testlerin yapılması ile aminoglikozidlerin emniyetli bir şekilde kullanılması sağlanabilmektedir. ${ }^{[36]}$

\section{Trimetoprim-Sulfametoksazol (TMP/SMX)}

Avantajları; Uygun oral biyo-kullanılabilirliği, oral ve intravenöz formunun olması, prostata penetrasyonunun iyi olması, rölatif olarak pahalı olmaması ve gr (-) patojenlerin çoğuna karşı etkili olmasıdır.

Dezavantajları ise; pseudomonas'a karşı etkili olmaması, Enterokoklara karşı etkisinin fazla olmaması, bazı Enterobacteriaceae' ların ilaca karşı dirençli olması ve atipik patojenlere karşı etkili olmamasıdır.

\section{Opsiyonel Tedavi Seçenekleri}

Kronik oral antibiyotik supresyonu (3:A): Hastalığın üriner semptomlarını sınırlamak, idrarda bakteri üremesini 
azaltmak veya elimine etmek için önerilmektedir. Kronik supresyon tedavisinde; sadece idrarda yeterli ilaç düzeylerinin olması gereklidir. Prostata penetrasyonunu gerektirmemektedir. Böylece, daha emniyetli yan etki profili olan birçok ilaç seçilebilmektedir (Nitrofurantoin ve sefalosporinler gibi).

Örneğin; trimetoprim-sulfametoksazol (40 ve $200 \mathrm{mg}$, günde 1 defa),

Nitrofurantoin (50 veya $100 \mathrm{mg}$, günde 1 defa) bu amaç için belirgin bir şekilde etkili ilaçlardır.

\section{Akut semptomatik atakların aralıklı antimikrobiyal te- davisi (3:A), veya}

Radikal TUR-P veya açık prostatektomi; Tüm diğer tedaviler yetersiz kaldığında (4:C), prostat sıvısında aynı bakterinin sürekliliğinde ve büyük prostat taşları varlığında.

\section{Lokal olarak enjekte edilen antimikrobiyal ilaçlar?}

Prostatın içerisine antibiyotiklerin lokal olarak enjeksiyonunun, randomize kontrollü çalışmalar (RCT) olmamasına rağmen etkili olduğu bildirilmektedir. Bu sayede, antibiyotiklerin kullanımına izin vermede prostat kapsülü bypass edilmektedir. Küçük olgu serilerinde cesaret verici sonuçlar gösterilmiştir. Küçük hasta sayılı bir RCT'de; amikasine duyarlı prostat sekresyonlu 50 erkeğe 10 gün, amikasin, transrektal yolla submukozal olarak enjekte edilmiş. Aynı süre ile verilen IM amikasin enjeksiyonu ile karşılaştırıldığında, 3. aydaki klinik ve bakteriyolojik kür oranlarında anlamlı olarak düzelme olduğu gösterilmiştir.

\section{Multimodal Yaklașım}

Tek ajanla yapılan tedavilerden daha iyi semptom kontrolü sağlanmaktadır.

Alfa-blokerler (3:C): Üriner semptomları olan hastalarda, antimikrobiyal + alfa bloker kombinasyonu; yüksek nüks oranlarını azaltabilmektedir ve obstrüktif işeme semptomları olan hastalarda düşünülmelidir.

Bitki Ekstreleri: Florokinolonların, değişik bitki ekstreleri ile kombinasyonunun, yan etki oranlarında artış olmaksızın klinik semptomları hafifletebildiği gösterilmiştir.

Analjezik +/-Nonsteroidal anti-inflamatuvar ilaçlar (NSAID): Semptomların gerilemesinde (ağrı varlığında) ve yaşam kalitesinin düzelmesinde, yararlı olabilmektedir. NSAID'lerin uzun süreli kullanımı, yan etki profillerinden dolayı sınırlandırılmalıdır.

\section{Herbal ürünler ve Probiyotikler ile Adjuvan} tedavi

Serenoa repens ekstresi gibi bitkisel ürünler ve probiyotikler ile adjuvan tedavi üzerine birkaç küçük çalışma bulunmaktadır. Kombine tedavilerin CBP'li hastalarda florokinolonların klinik ve mikrobiyal etkinliğini düzeltebildiği gösterilmiştir. CBP'li ve irritabl barsak sendromlu hastalarda, probiyotikler ile uzun süreli bir tedavinin, prostatitin progresyonunu azalttığı da gözlenmiştir. ${ }^{[37]}$

\section{CBP'li hastaların partnerlerinin jinekolojik olarak araștırılması}

İnsan vajinası, bir ekosistem lokalizasyonudur. İnsan vajeni, farklı katılımcıların (yerel mikrobiyal popülasyonlar, yerel çevre ve ev sahibinin özellikleri) her zaman dinamik bir dengede olduğu bir ekosistem bölgesidir. Bu ekosistem hem dışarıdan hem de intestinal çevreden kontaminasyona açıktır. Böylece, bakteri sayılarına göre simbiyotik veya patojenik olabilen mikroorganizmaların kolonizasyonuna ve vajinal homeostatik mekanizmaları değiştirme yeteneklerine karşı duyarlıdır. Vajinal ekosisteme tüm katılanlar (vajinal epitelyum, $\mathrm{pH}$, glikojen ve laktobasiller flora) farklı hormonal üretimi nedeniyle bir kadının farklı yaşları boyunca modifiye olmaktadır. Puberte veya gebelik esnasındaki gibi yüksek bir östrojen üretimi proliferasyona ve glikojen depolamaya vajen hücrelerini stimüle etmektedir. Ayrıca, glikojen, laktik asit üretimini ve vajinal $\mathrm{pH}$ 'ın düşürülmesini kolaylaştırır. Bundan başka, lactobaciller flora, patojenlerin büyümesini ve onların vajen epiteline yapışmasını durduğundan dolayı koruyucu bir role sahiptir. ${ }^{[38,39]}$ Tüm bu mekanizmalar vajenin savunmasında ilk hattır. Ayrıca, menstrüel siklüslerin, cinsel aktivitenin, antibiyotiklerin veya oral kontraseptiflerin vajinal makrobiyotikleri değiştirebileceği farz edilmektedir. Vajinal mikrobiyota, gebe kalma ve doğum mekanizmalarında aktif bir rol oynamaktadır (zaman ve modalite). ${ }^{[40]}$ Vajinal homeostazın bozulması varlığında (konağın farklı duyarlılığ1 veya kontrol mekanizmalarının değişmesi nedeniyle), eksternal patojenlerden saldırı nedeniyle veya disbiyozis (Vücuttaki mikrobiyal dengesizliklerin neden olduğu tıbbi durum) (vajinozis) nedeniyle lokal floranın kantitatif yeniden dağılması nedeniyle vajinal enfeksiyonlar (vajinit) oluşabilmektedir. Doğru bir tanı için, hastanın klinik öyküsünün, karakteristik işaretlerin veya semptomların, vajen pH'sının, balık kokusu testinin, boyamalı veya boyamasız mikroskopik muayene ve bir kültür/moleküler testinin değerlendirilmesi önemlidir. CP/CPPS'den muzdarip 399 hastanın eşlerine vajinal, servikal veya uretral sürüntünün yapıldığı bir çalışmada, erkeklerle aynı patojen gösterilmiş (Enterobacteria, ureoplazma urelitikum, Gardnerella vaginalis ve klamidya. ${ }^{[41,42]}$ 


\section{Avrupa Üroloji Kılavuzları (EAU-2018)}

Florokinolonlar, üropatojenlerin yüksek direnç oranlarına rağmen, uygun farmakokinetik özelliklerinden dolayı, CBP'nin ampirik tedavisinde ilk basamak tedavi olarak önerilmektedir. P. aeruginosa ve $K$. trachomatis enfeksiyonlarını içeren gram negatif patojenlere karşı antibakteriyel özelliklere sahiptir (Tablo 1,2).

Azitromisin ve doksisiklin, genital mikoplazmalar ve $K$. trachomatis gibi atipik patojenlere karşı etkilidir.

Metronidazol tedavisi, T. vaginalis enfeksiyonu olan hastalarda endikedir. Tedavi, $500 \mathrm{mg} 14$ gün, günde üç defa verilmelidir. Mikroorganizma eradikasyonu \%93,3 olarak bildirilmiştir. Antimikrobiyalların intraprostatik enjeksiyonları, kontrollü çalışmalarla değerlendirilmediği için önerilmemektedir.

Tedaviye rağmen, semptomların uzun sürmesi durumunda, CPPS'nin yanı sıra diğer ürogenital ve ano-rektal bozukluklar da göz önünde bulundurulmalıdır. CBP semptomları, prostat tüberkülozunu gizleyebilmekte, maskeleyebilmektedir. Tüberküloz öyküsü olan veya tüberkülozun endemik olduğu bölgelerdeki erkeklerdeki pyospermi ve hematospermi durumunda ürogenital tüberküloz araştırılmalıdır. CBP'de spektrum geniştir ve atipik mikroorganizmaları da içerebilmektedir. İmmun yetmezliği olan veya HIV (+) hastalarda prostatit; M. tuberkulosis, Candida suşları, ve Coccidioides immitis, Histoplasma capsulatum ve Blastomyces dermatitidis gibi nadir patojenler gibi zor enfeksiyon yapan patojenlerle de oluşabilmektedir.

Prostat biyopsisi rutin olarak önerilmemektedir. Tedavisiz bakteriyel prostatitli hastalarda da sepsis riskinden dolayı da önerilmemektedir.

Tablo 1. EAU-CBP için önerilen antimikrobiyal tedavi rejimleri

\begin{tabular}{lccc} 
Antimikrobiyal & Günlük doz & $\begin{array}{c}\text { Tedavi } \\
\text { süresi }\end{array}$ & Yorum \\
\hline Florokinolon & $\begin{array}{c}\text { Optimal oral } \\
\text { günlük doz }\end{array}$ & $\begin{array}{c}4-6 \\
\text { hafta }\end{array}$ & \\
\hline Doksisiklin & $\begin{array}{c}100 \mathrm{mg}, 2 \\
\text { defa/G }\end{array}$ & $\begin{array}{c}10 \\
\text { gün }\end{array}$ & $\begin{array}{c}\text { sadece } \text { K. trachomatis } \\
\text { veya mikoplazma } \\
\text { enfeksiyonları }\end{array}$ \\
\hline Azitromisin & $\begin{array}{c}500 \mathrm{mg}, 3 \mathrm{x} \\
\text { haftalık }\end{array}$ & $\begin{array}{c}3 \\
\text { hafta }\end{array}$ & $\begin{array}{c}\text { K. trachomatis } \\
\text { enfeksiyonları }\end{array}$ \\
\hline $\begin{array}{l}\text { Metronidazol } \\
\text { takip }\end{array}$ & $\begin{array}{c}500 \mathrm{mg} \mathrm{3} \\
\text { defa/G }\end{array}$ & $\begin{array}{c}14 \\
\text { gün }\end{array}$ & $\begin{array}{c}\text { sadece } \text { T. vaginalis } \\
\text { enf.'ları }\end{array}$ \\
\hline
\end{tabular}

Tedavi sonrası asemptomatik olan hastalarda, rutin idrar tetkiki ve/veya idrar kültürü zorunlu değildir. Semptomların geçmesi hariç, bakteriyel prostatitin kür olduğuna dair geçerli testler bulunmamaktadır. Dirençli semptomları olan ve cinsel yolla geçen enfeksiyöz patojenler için tekrarlayan mikrobiyal kültürleri pozitif gelen hastalarda, hastanın cinsel eşi de mikrobiyolojik olarak taranmalı ve gerektiğinde tedavi edilmelidir. Antibiyotik tedavileri daha uzun süreler ve daha yüksek dozlar ve/veya farklı bileşikler ile tekrarlanabilmektedir.

Tablo 2. Bakteriyel prostatitin tedavi önerileri ve kanıt düzeyleri (EAU-2018)

Kanıt özeti

ABP'nin tedavi rejimleri klinik tecrübeler ve kontrolsüz klinik çalışmalara dayanmaktadır. Sistemik hastalık semptomları olan ABP'li hastalarda, parenteral antibiyotik tedavisi tercih edilmeli. Enfeksiyon parametrelerinin normalleşmesinden sonra oral tedaviye geçilebilir ve toplamda 2-4 hafta tedavi sürdürülmelidir.

CBP için antimikrobiyal tedavide ilk basamak ilaçları olarak florokinolonların rolü sistematik bir derlemede konfirme edilmiştir. Levofloksasin, Siprofloksasin ve Prulifloksasin arasında klinik etkinlik, mikrobiyolojik eradikasyon ve yan etkiler bakımından anlamlı fark gözlenmemiştir.

Zorunlu intraselüler patojenlerin neden olduğu CBP'li hastalarda, makrolidler, florokinolonlar ile karşılaştırıldığında daha yüksek klinik ve mikrobiyolojik kür oranlarına sahiptir.

Klinisyenler, antibiyotik seçerken lokal ilaç direnci özelliklerini de düşünmelidir.

Tablo 3. EAU

\begin{tabular}{|c|c|}
\hline Öneriler & $\begin{array}{c}\text { Güçlülük } \\
\text { oranı }\end{array}$ \\
\hline \multicolumn{2}{|l|}{ Akut bakteriyel prostatit } \\
\hline Komplike UTI önerilerine göre ABP'yi tedavi et & Güçlü \\
\hline $\begin{array}{l}\text { Kronikbakteriyel prostatit (CBP) } \\
\text { illk basamak tedavisi için bir florokinolon reçete et } \\
\text { (örn., siprofloksasin, levofloksasin) }\end{array}$ & Güçlü \\
\hline $\begin{array}{l}\text { CBP'nin nedeni olarak, intraselüler bir bakteri } \\
\text { saptanmışsa, bir makrolid (örn., azitromisin) veya bir } \\
\text { tetrasiklin reçete et (örn., doksisiklin) }\end{array}$ & Güçlü \\
\hline CBP nedeni $T$. vajinalis ise, metronidazol reçete et & Güçlü \\
\hline
\end{tabular}

\section{SONUÇ}

Prostatit tablolarının birbirine dönüşme özelliği bulunmaktadır. Akut bakteriyel prostatit hastalarının \%10 kadarında kronik bakteriyel prostatit gelişebilmekte ve kronik bakteriyel prostatit hastalarının da yaklaşık \%10'u kronik pelvik ağr1 sendromuna dönüşebilmektedir. Bu nedenle tedavi için bir antibiyotik seçerken, prostata geçişi ve ilaç direnci gibi özellikleri de göz önüne alınmalıdır. 


\section{Hakem Değerlendirmesi}

Dış bağımsız

Çıkar Çatışması

Yazarlar çıkar ilişkisi olmadığını beyan etmişlerdir.

\section{Finansal Destek}

Herhangi bir mali destek alınmamıștır.

\section{Peer-review}

Externally peer-reviewed.

\section{Conflict of Interest}

No conflict of interest was declared by the authors.

\section{Financial Disclosure}

No financial disclosure was received.

\section{KAYNAKLAR}

1. Stamey TA. Prostatitis. J Royal Soc Med 1981;74:22-40. [CrossRef]

2. Young HH, Geraghty JT, Stevens AR. Johns Hopkins Hospital Reference Group (PERG). Diagnosis and treatment of chronic bacterial prostatitis. Reports 1906;13:272-34.

3. von Staden H. Herophilus, Herophilus Chalcedonius, The art of medicine in early Alexandria: Edition, Translation and Essays. Cambridge: Cambridge University Press, 1989.

4. Stutzman RE, Walsh PC. In: Suprapubic and retropubik prostatectomy, 6th ed. Walsh PC, Retik AB, Stamey TA, Vaughan ED Jr, editors. Philadelphia: WB Saunders Co.; 1992. p.2851-6.

5. Meares EW, Stamey TA. Bacteriologic localization patterns in bacterial prostatitis and urethritis. Invest Urol 1968;5:492-518. https://pubmed.ncbi.nlm.nih.gov/4870505/

6. Drach GW, Meares EM, Fair WR, Stamey TA. Classification of benign disease associated with prostatic pain: prostatitis or prostatodynia? J Urol 1978;120:266. [CrossRef]

7. Krieger JN. NIH consensus definition and classification of prostatitis. JAMA 1999;282:236-7. [CrossRef]

8. Schaeffer AJ, Wendel EF, Dunn JK, Grayhack JT. Prevalence and significance of prostatic inflammation. J Urol 1981;125:215-9. [CrossRef]

9. Clemens JQ, Meenan RT, O'Keeffe Rosetti MC, Gao SY, Calhoun EA. Incidence and clinical characteristics of National Institutes of Health type III prostatitis in the community. J Urol 2005;174:2319-22. [CrossRef]

10. Krieger JN, Riley DE, Cheah PY, Liong ML, Yuen KH. Epidemiology of prostatitis: new evidence for a world-wide problem. World J Urol 2003;21:70-4. [CrossRef]

11. Nickel JC, Downey J, Hunter D, Clark J. Prevalence of prostatitislike symptoms in a population based study using the National Institutes of Health chronic prostatitis symptom index. J Urol 2001;165:842-5. [CrossRef]

12. Khan FU, Ihsan AU, Khan HU, Jana R, Wazir J, Khongorzul P, et al. Comprehensive overview of prostatitis. Biomed Pharmacother 2017;94:1064-76. [CrossRef]

13. Nickel JC, Downey JA, Nickel KR, Clark JM. Prostatitis-like symptoms: one year later. BJU Int 2002;90:678-81. [CrossRef]

14. Calhoun EA, McNaughton Collins M, Pontari MA, O'Leary M, Leiby BE, Landis JR, et al. The economic impact of chronic prostatitis. Arch Intern Med 2004;164:1231-6. [CrossRef]

15. Coker TJ, Dierfeldt DM. Acute Bacterial Prostatitis: Diagnosis and Management. Am Fam Physician 2016;15;93:114-20. https:// www.aafp.org/afp/2016/0115/p114.html

16. Nickel JC, Shoskes D, Wang Y, Alexander RB, Fowler JE, Zeitlin S, et al. How does the pre-massage and post-massage 2-glass test compare to the Meares-Stamey 4-glass test in men with chronic prostatitis/ chronic pelvic pain syndrome? J Urol 2006;176:119-24. [CrossRef]
17. Bozeman CB, Carver BS, Eastham JA, Venable DD. Treatment of chronic prostatitis lowers serum prostate specific antigen. J Urol 2002;167:1723-6. [CrossRef]

18. Weidner W, Schiefer HG, Krauss H, Jantos C, Friedrich HJ, Altmannsberger M. Chronic prostatitis: a thorough search for etiologically involved microorganisms in 1,461 patients. Infection 1991;19:S119-25. [CrossRef]

19. Polascik TJ, Oesterling JE, Partin AW. Prostate specific antigen: a decade of discovery-- what we have learned and where we are going. J Urol 1999;162:293-306. [CrossRef]

20. Gill BC, Shoskes DA. Bacterial prostatitis. Curr Opin Infect Dis 2016;29:86-91. [CrossRef]

21. Neal DE Jr, In: Nickel JC, editor. Textbook of Prostatitis. Oxford: ISIS Medical Media; 1999. p.279-84.

22. Yoon BI, Kim S, Han DS, Ha US, Lee SJ, Kim HW, et al. Acute bacterial prostatitis: how to prevent and manage chronic infection? J Infect Chemother 2012;18:444-50. [CrossRef]

23. Nickel JC. Prostatitis. CUA Guideline. Can Urol Assoc J 2011;5:306-15. [CrossRef]

24. Campeggi A, Ouzaid I, Xylinas E, Lesprit P, Hoznek A, Vordos D, et al. Acute bacterial prostatitis after transrectal ultrasound-guided prostate biopsy: epidemiological, bacteria and treatment patterns from a 4-year prospective study. Int J Urol 2014;21:152-5. [CrossRef]

25. McNaughton-Collins M, Pontari MA, O’Leary MP, Calhoun EA, Santanna J, Landis JR. Quality of life is impaired in men with chronic prostatitis. J Gen Intern Med 2001;16:656-662. [CrossRef]

26. Workshop Committee of the National Institute of Diabetes and Digestive and Kidney Disease (NIDDK). Chronic Prostatitis workshop 1995: Bethesda, Maryland.

27. Krieger JN, Egan KJ, Ross SO, Jacobs R, Berger RE. Chronic pelvic pains represent the most prominent urogenital symptoms of "chronic prostatitis". Urology 1996;48:715-22. [CrossRef]

28. Nickel JC. Effective office management of chronic prostatitis. Urol Clin North Am 1998;25:677-84. [CrossRef]

29. Nickel JC, Teichman JM, Gregoire M, Clark J, Downey J. Prevalence, diagnosis, characterization, and treatment of prostatitis, interstitial cystitis, and epididymitis in outpatient urological practice: the Canadian PIE Study. Urology 2005;66:935-40. [CrossRef]

30. Schaeffer AJ, Datta NS, Fowler JE Jr, Krieger JN, Litwin MS, Nadler RB, et al. Overview summary statement. Diagnosis and management of chronic prostatitis/chronic pelvic pain syndrome (CP/CPPS). Urology 2002;60(6 Suppl):1-4. [CrossRef]

31. Bassetti M, Carnelutti A, Peghin M. Patient specific risk stratification for antimicrobial resistance and possible treatment strategies in gram-negative bacterial infections. Expert Rev Anti Infect Ther 2017;15:55-65. [CrossRef]

32. Lipsky BA, Byren I, Hoey CT. Treatment of bacterial prostatitis. Clin Infect Dis 2010;50:1641-52. [CrossRef]

33. Zhanel GG, Zhanel MA, Karlowsky JA. Oral Fosfomycin for the Treatment of Acute and Chronic Bacterial prostatitis Caused by Multidrug-Resistant Escherichia coli. Can J Infect Dis Med Microbiol 2018;2018:1404813. [CrossRef]

34. Kobayashi I, Ikawa K, Nakamura K, Nishikawa G, Kajikawa K, Yoshizawa T, et al. Penetration of piperacillin-tazobactam into human prostate tissue and dosing considerations for prostatitis based on site-specific pharmacokinetics and pharmacodynamics. J Infect Chemother 2015;21:575-80. [CrossRef]

35. Nishikawa G, Ikawa K, Nakamura K, Yamada Y, Zennami K, Mitsui K, et al. Prostatic penetration of meropenem in humans, and dosage considerations for prostatitis based on a site-specific pharmacokinetic/pharmacodynamic evaluation. Int J Antimicrob Agents 2013;41:267-71. [CrossRef] 
36. Grayson ML, Macesic N, Trevillyan J, Ellis AG, Zeglinski PT, Hewitt NH, et al. Fosfomycin for Treatment of Prostatitis: New Tricks for Old Dogs. Clin Infect Dis 2015;1;61:1141-3. [CrossRef]

37. Krieger JN, Lee SW, Jeon J, Cheah PY, Liong ML, Riley DE. Epidemiology of prostatitis. Int J Antimicrob Agents 2008;31:8590. [CrossRef]

38. Ravel J, Gajer P, Abdo Z, Schneider GM, Koenig SSK, McCulle $\mathrm{SL}$, et al. Vaginal microbiome of reproductive-age women. Proc Natl Acad Sci U S A 2011;108:4680-7. [CrossRef]

39. Lepargneur JP, Rousseau V. Protective role of the Doderleïn flora. J Gynecol Obstet Biol Reprod (Paris) 2002;31:485-94.
40. Amabebe E, Anumba DOC. The vaginal microenvironment: the physiologic role of lactobacilli. Front Med (Lausanne). 2018;5:181. [CrossRef]

41. Unemo M, Bradshaw CS, Hocking JS, de Vries HJC, Francis SC, Mabey D, et al. Sexually transmitted infections: challenges ahead. Lancet Infect Dis 2017;17:e235-79. [CrossRef]

42. Vitali B, Cruciani F, Picone G, Parolin C, Donders G, Laghi L. Vaginal microbiome and metabolome highlight specific signatures of bacterial vaginosis. Eur J Clin Microbiol Infect Dis 2015;34:2367-76. [CrossRef] 